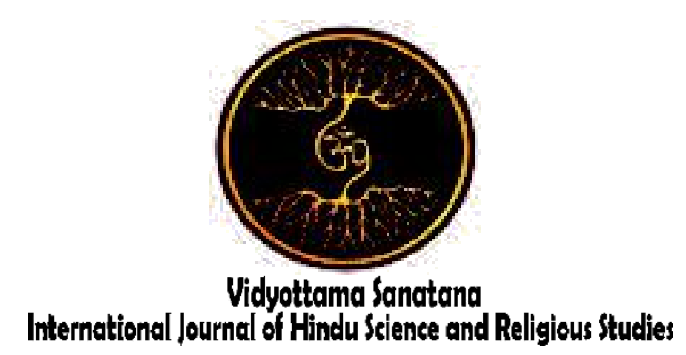

Vol. 3 No. 2 October 2019

\title{
THE IMPLEMENTATION OF THE WARIGA DEWASA ON PANCA YAJÑA CEREMONY IN MATARAM CITY
}

\author{
By: \\ I Made Agus Yudhiarsana ${ }^{1}$, I Gusti Ngurah Sudiana², I Made Girinata ${ }^{3}$ \\ ${ }^{1}$ STAHN Gde Pudja Mataram \\ ${ }^{23}$ Institut Hindu Dharma Negeri Denpasar \\ E-mail : ${ }^{1}$ yudherini28@yahoo.co.id
}

Received: August 2, 2019

Accepted: September 18, 2019

Published: October 31, 2019

\begin{abstract}
The evolution of the implementation of wariga dewasa is reflected in the transformation of the day or padewasan for the panca yajña ceremony in the Hindu community in Mataram City. As a result of the rational, pragmatic and critical rationale of modern urban society, with negative access to individual nature and consumerism dominated by industrial pragmatic interests. The implementation of wariga dewasa can be seen from the nunas dewasa tradition for the Dewa Yajña, Pitra Yajña and Butha Yajña ceremonies that have not changed much, especially the Rsi Yajñ ceremony with the Guru Nabe hegemony in the aguron-guron tradition. The change in the implementation of wariga dewasa occurred at the Manusa Yajña ceremony from the quality of the padewasan based on alahing sasih, which is increasingly supported by the banten pemarisudha mala dewasa as a neutralizing for the influence of dewasa ala from the day of the ceremony. Transformation is caused by changes in the system of values and beliefs of society, globalization, economic influence and the existence of manggala yajña. Resulting in the degradation of the symbolic meaning of wariga dewasa, social and cultural changes, for example changes in the tradition of nunas padewasan, the negative influence of populist economic development on economic aspects, and redefinition of people's perceptions about the effects of padewasan and the purpose of banten pemarisudha mala dewasa.
\end{abstract}

Keywords: Implementation, Wariga Dewasa, Padewasan, Panca Yajña. 


\section{INTRODUCTION}

Nowadays, urban communities are starting to use their thinking in living all aspects of their lives in the community. Likewise in relation to the implementation of the panca yajña ceremony, both nitya yajña and naimitika yajña. The values of professionalism, efficiency and effectiveness begin to underlie all considerations in the implementation of the panca yajñas, so they begin to shift the values of adat, ethics and mutual cooperation, even the philosophical values of a ceremony and accompanying ceremony. This also applies to the determination of the day and time of the performance of a panca yajña ceremony. Determination of days for Naimitika yajñas which are carried out periodically or at certain times by the wariga calculation system, as well as the time of performing yajñas that are routine, which includes nitya yajñas that do not require a special calculation system.Kehidupan manusia akan selalu mengalami perubahan, karena segala yang ada di alam akan terpengaruh oleh waktu, begitu juga dengan kehidupan umat Hindu khususnya pada pelaksanaan ritual atau upacara panca yajña yang terjadi dalam komunitas Hindu di Kota Mataram. Terjadi evolusi pemahaman dan implementasi wariga dewasa oleh umat Hindu di Kota Mataram, yang tercermin dalam transformasi pelaksanaan upacara yajña khususnya dari segi hari atau padewasan pelaksanaan upacara panca yajña itu sendiri.

In traditional societies that are still dominated by traditional values and traditions, the community still holds fast to the panca yajña ceremonies that are trusted and carried on for generations. Follow and do what is custom and culture based on the values of religious teachings, without criticizing and deconstructing all the routines that they do. However, the characteristics of traditional community life that still adhere to the values of customs, ethics, mutual cooperation, and various values as the implementation of religious teachings, began to disappear in the life of modern urban society.
Positive access to the rational act of values by Max Weber in the life of modern society can also be seen from the efforts of his community in increasing their knowledge and understanding of the value of philosophy or tattva implementation of the panca yajña ceremony. As a form of implementing basic rational and critical thinking that develops in modern society. However, it cannot be denied, the negative excess of a rational thought which is dominated by industrial interests as one of the characteristics of modern society, causes the re-emergence of symbolic degradation of a value.

Various forms of panca yajña ceremonies and ceremonial processions wrapped in cultural art elements are packaged in the form of symbols based on Hinduism teachings contained in the implementation of the panca yajña ceremonies, when meeting economic and industrial interests that are rooted in urban life, will lead the community to an a heavy choice between meeting physical or spiritual needs. Human needs for the existence and imaging of individuals in social relations in their communities, as well as easy access to consumer goods, in reality will lead people to tend to physical or physical fulfillment. Making spiritual fulfillment a priority scale of the second, or even the last, including the implementation of the Yajña ceremony.

Hindus in the city of Mataram in the practice of religious life, mainly performing rituals, still use the calculation of days based on wariga dewasa, through the tradition of nunas dewasa to the manggala yajña. In the process of implementing wariga dewasa both to the pemangku (Pinandita) or the sulinggih (Pandita) there are procedures, ethical values and ceremonies that are still maintained by the Hindu community in the Mataram City.

One element of the implementation of the panca yajña ceremonies is padewasan on the basis of Wariga as a system of determining the good days in the implementation of the panca yajña ceremonies, starting to be questioned and studied, as a form of adaptation and 
evolution of community thought in its efforts to adapt to modern urban life. Economic principles and logic as well as material orientation, technological progress and industrialization, individualization, differentiation and acculturation as a characteristic of modernization in urban society (Setiadi et al, 2016: 61), as well as a mindset that focuses more on science and technology with their rational thoughts and actions rational thinking (Sajogyo, 1985: 112), became a number of factors that influenced the development of the religious ritual life in urban communities. As happened to the Hindu community in the Mataram City, West Nusa Tenggara.

The life of a modern society characterized by rational thought with individual and pragmatic attitudes, interpreting the complexity of determining padewasan with various existing components, becomes an obstacle in the implementation of the yajña ceremony which is practical and flexible in terms of the day and time of its implementation. So that the community carried out the reconstruction of the meaning of the importance of fulfilling the quality of the basic components of padewasan in accordance with the wariga dewasa, which had an impact on symbolic degradation and shifts in the meaning of wariga dewasa in the supporting community.

In the implementation of the nunas dewasa tradition which aims to get good padewasan or ayuning dewasa yajña ceremonies, there appears to be a tendency for the dominance of the interests of certain days by the yajamana. It gives an impression which only seeks legality and justification, for the day of the yajña ceremony the yajamana wants from the manggala yajña. The phenomenon that occurs in the life of Hindus in the city of Mataram, due to the development of mindset and rationalization of the community, especially regarding the implementation of the panca yajñas in terms of padewasan.

\section{RESULTS AND DISCUSSION}

\subsection{Wariga Dewasa Of The Panca Yajña Ceremony In The Mataram City}

Religion as a form of human activity involving feelings or sentiments which are considered as a process of surrender to the substance called God, because it is considered as the creator, regulator, and determinant of the path of human life. From religion will bring up the existence of rites and ceremonies as a manifestation of the needs of human practice in social life, to be able to relate or communicate, and realize the human sense of service itself to God (Nasruddin, 2013:55).

Hindus have various rites or ceremonies which are included in the panca yajñas. Related to what was stated by William Robertson Smith in Koentjaraningrat (2007: 167-168), the panca yajña ceremonies in Hinduism will always remain and be carried out, but there will always be a possibility of shifts or changes that are both evolutionary and revolutionary in their implementation. Changes that occur can be in the form of the background of the implementation, belief and purpose of the implementation of the ceremonies in the panca yajñas, to the doctrine that underlies the ritual or ritual itself. This includes the use of wariga dewasa in determining the good day of the panca yajña ceremony.

Changes in the panca yajña ceremonies can occur evolutionarily in a slow and gradual period of time, with a series of small changes occurring in the ceremonial means, the ceremonial administration, as well as the basic concepts of the ceremony. Wariga dewasa as a basis for calculating the day of the yajña ceremony, also experienced changes in its application in the community. This change can occur based on the agreement of the manggala yajña and the yajamana.

The transformation of the procedures and forms of communication in the tradition of nunas dewasa influenced by modernization of technology and rational thought, into a simple and practical form of communication. The lack of interaction that 
occurs in the tradition of nunas dewasa reduces the preservation of the Balinese language, the cultivation of ethics and ethics for the younger generation of Hindus and the emotional closeness of the people with Pandita and Pinandita. The upakara used is enough to bring the canang sari as a banten penuur, accompanied by rice, coffee, sugar and incense.

The implementation of the nunas dewasa tradition regarding the day of the Dewa Yajña ceremony, such as the Ngeruwak Karang, Makuh and Melaspas (Merajan or Temples), as well as a place to stay (home), there is no meaningful debate in the dialogue process between the Yajamana with The Manggala Yajña. Moreover, when it comes to carrying out the Ngenteg Linggih ceremony, which has generally been planned in advance. Rsi Yajña ceremonies held in the Mataram City, such as the Diksa and Pawintenan ceremonies, did not change significantly. The process of learning or pasisyan by the people to Nabe, or Pinandita to Pandita Nabe, giving the position or social strata higher to the Nabe in deciding when students may undergo the Pawintenan or Padiksan ceremony. So that the padewasan or day of the Pawintenan or Padiksan ceremony is generally directly determined or given by the Manggala Yajña or the Pandita Nabe himself.

On the implementation of the nunas dewasa tradition regarding the day of the Pitra Yajña ceremony, such as Ngaben and Mamukur, between the Yajamana and the Manggala Yajña there was no meaningful debate. Moreover, when it comes to implementing Ngaben ceremonies that are immediate or impromptu. Just avoid the abstinence of the days that fall on Tri Wara Pasah, Anggara Kasih, Buddha Wage, Buddha Kliwon, Tumpek and Purwani. Butha Yajña namely renewal follows piodalan (Dewa Yajña), Ngaben (Pitra Yajña), and other Panca Yajña ceremonies, because renewal is present at every Panca Yajña. Butha Yajña still follows the rules of the Wariga Dewasa that suggested by Pandita and Pinandita as the Manggala Yajña through the tradition of nunas dewasa.

The development of the era and the modern mindset of the community, with rational thoughts based on the value of effectiveness, efficiency and professionalism supported by easy access to information, began to influence the way of Hindu views on the symbolization and meaning of the padewasan methods in carrying out the pawiwahan or marriage ceremony (Manusa Yajña). Dialogue on various considerations in determining padewasan, which occurred between the yajamana and the manggala yajña, is the beginning of the process of shifting the quality of padewasan. The change in the meaning of the importance of padewasan which must meet at least half the components of alahing sasih, is increasingly supported by the offer of an pemarisudha mala dewasa, as a neutralizing the influence of dewasa for the affect of the implementation of the yajña ceremony.

\subsection{Causes of Changes In The Use Of Wariga Dewasa In The Implementation Of The Panca Yajña Ceremony In Mataram City}

The evolution or revolution in the implementation of rites or ceremonies will always occur as well as in the implementation of panca yajñas by the Hindus comunity in the Mataram City, because everything in human culture is subject to change (Nordskog in Garna, 1992: 19). Culture has an adaptive nature, creating a new tool for adaptation to the conditions of life for humans, especially those that occur in Hindu communities in urban areas.

The development of society and its environmental conditions towards a higher complexity as a result of human evolution, leading humans to the development of socioculture in which a new culture that rivaled the old culture was finally able to replace the old culture (Sanderson, 2003: 45). The change in mindset of the Hindu community in the Mataram City as a result of the evolutionary process that occurs socially and culturally, from a traditional agrarian 
mindset to a modern industry based on the rationalization of thought, has an impact on the shifting of perceptions and implementation of Hindu wariga dewasa in carrying out the panca yajña ceremony.

Changes in the application of wariga dewasa in the panca yajña ceremony in the Mataram City are due to changes in the value system of people's beliefs, globalization, economy and the existence of the manggala yajña. Changes in the value system and perceptions of the community supporting wariga dewasa. There is a redefinition of the system of values and beliefs and new perceptions of quality, by only considering a number of components, even only one component is very low. However, the use of wariga in intensity through the tradition of nunas dewasa or niwakang dewasa the implementation of the panca yajña ceremony is still maintained and is carried out by Hindus in the Mataram City. Individualist and pragmatic understandings of globalization have resulted in changes in the manner and form of communication of the nunas dewasa tradition.

Globalization which provides ease of distance and time with its transportation technology, based on pragmatic values, only refers to the application of communication technology alone. Having a tendency to interact through a form of verbal communication, limited, without direct interaction with various positive sides that can be accepted in the tradition of nunas dewasa. Modern thinking with its rational characteristics leads people with their pragmatic logic to simplify ceremonies and ceremonial procedures, including simplifying the deciding components of the formulation of the padewasan implementation of the panca yajña ceremonies, so as to get the day according to their wishes rather than being guided by wariga dewasa.

Economic influence in the economic aspect, lifestyle and the influence of consumerism in the modern world, the Hindu community in the Mataram City struggling with the material world, places religious rituals in a secondary position, with various adjustments in the form of simplifying ceremonies, ceremonies material, until the time or padewasan of the panca yajña ceremonies.

The existence of Pandita and Pinandita based on their role as manggala yajña. Rational thinking based on various personal interests of the society led to the redefinition and criticism of rituals by Hindus in the Mataram City, to the complexity of the implementation of the yajña ceremony, especially the determination of the days of implementation. The manggala yajña gave a positive response by giving legality as a form of flexibility of Hindu religious rituals, while providing improvements to the Hindu perception of the yajña ceremony, so as not to eliminate the essence of Hindu religious teachings.

\subsection{Implications Of Wariga Dewasa At The Panca Yajña Ceremony In Mataram City}

The application of Wariga Dewasa at the Panca Yajña ceremony has implications for symbolic, social and cultural, economic and people's perceptions. The implication of the symbolic meaning can be seen from the formation of belief in the concept of wariga dewasa, as a solution to the lack of ayuning dewasa due to the complexity of the calculation of existing padewasan, as the reason for the use of an banten pemarisudha mala dewasa. Pragmatic demands and rational thinking about the efficiency and effectiveness of time, by active and dynamic Hindus in the Mataram City, on the one hand get practical solutions from the presence of banten pemarisudha mala dewasa.

However, it has formed new perceptions that lead to the degradation of the symbolic meaning of alahing sasih in the thinking of its user community, regarding the selection of padewasan which must meet at least half the components of alahing sasih in wariga dewasa. Social and cultural implications have an impact on changes in the manner and form of communication and ceremonial means in the tradition of nunas 
dewasa. Economic implications, impacting on the simplification of the basic components of the computation from the calculation of the implementation of the yajña ceremony, have a negative influence on the development of popular economy. In some types of ceremonies which include Dewa Yajña, such as the temple piodalan indeed have an impact on the reduced number of days of its implementation, it has a domino effect on the economic activities arising from the implementation of the piodalan ceremony. Implications for the perception of Hindus occur redefinition of community perceptions of the influence of the quality of padewasan and the use of banten pemarisudha mala dewasa.

\section{CONCLUSION}

The implementation of the nunas dewasa tradition regarding the day of the Dewa Yajña, Pitra Yajña, and Butha Yajña cereceremony does not mean a significant debate in the process of dialogue that happened between the Yajamana and the Manggala Yajña. Especially in the Rsi Yajña ceremonies held in the Mataram City, such as the Diksa and Pawintenan ceremonies, did not change significantly. The process of learning or pasisyan by the people to Nabe, or Pinandita to Pandita Nabe, giving the position or social strata higher to the Nabe in deciding when students or sisya may undergo the Pawintenan or Padiksan ceremony. So that the dewasa or day of the Pawintenan or Padiksan ceremony is generally directly determined or given by the Manggala Yajña or the Pandita Nabe himself.

The development of the era and the modern mindset of the community, with rational thoughts based on the value of effectiveness, efficiency and professionalism supported by easy access to information, began to influence the way of Hindu society views on the symbolization and meaning of the padewasan methods in carrying out the marriage or pawiwahan ceremony (Manusa Yajña). Dialogue on various considerations in determining padewasan, which occurred between the yajamana and the manggala yajñ $a$, is the beginning of the process of shifting the quality of padewasan. The change in the meaning of the importance of padewasan which must meet at least half the components of alahing sasih, is increasingly supported by the existence of an banten pemarisudha mala dewasa, as a neutralizing the influence of the dewasa ala of the day of the Yajña ceremony.

There are factors that cause changes in the implementation of wariga dewasa in the panca yajña ceremonies, such as: (a) The value system and people's beliefs about wariga dewasa. (b) Globalization with advances in communication technology and easy access to information on religious rituals. (c) An economy with an individualistic, pragmatic lifestyle and materialism that places religious rituals especially wariga dewasa in a secondary position. (e) The existence of manggala yajña Pandita and Pinandita provides the legality of the desire of the people for padewasan, as a form of flexibility in Hindu rituals.

The implications of the application of Wariga Dewasa at the panca yajña ceremony can be seen from: (1) Implications of symbolic meaning. The formation of confidence in the concept of pemarisudha mala dewasa, as a solution to the lack of ayuning dewasa due to the complexity of the calculation of existing padewasan, is the reason for the use of an banten pemarisudha mala dewasa. Pragmatic demands and rational thinking about the efficiency and effectiveness of time, by active and dynamic Hindus in the Mataram City, on the one hand get practical solutions from the presence of banten pemarisudha mala dewasa. However, it has formed new perceptions that lead to the degradation of the symbolic meaning of alahing sasih in the thinking of its user community, regarding the selection of padewasan which must meet at least half the components of alahing sasih in wariga dewasa. (2) Social and Cultural Implications cause changes in the procedures and forms of communication and ceremonial means in the nunas dewasa tradition. The lack of 
interaction that occurs in the tradition of nunas dewasa reduces the preservation of the Balinese language, the cultivation of ethics and ethics for the younger generation of Hindus and the emotional closeness of the community with Pandita and Pinandita. The Upakara used is enough to bring the canang sari as a banten penuur, accompanied by rice, coffee, sugar and incense. (3) Economic implications, indirectly have a negative influence on the development of social economy, with the simplification of the number of days of yajña.

\section{REFERENCES}

Bustanuddin, Agus. 2006. Agama Dalam Kehidupan Manusia, Pengantar Antropologi Agama. Jakarta: Raja Grafindo Persada.

Damsar dan Indrayani. 2017. Pengantar Sosiologi Perkotaan. Cetakan ke-1. Jakarta: Kencana.

Garna, Judistira K. 1992. Teori-Teori Perubahan Sosial. Bandung: PPsUniversitas Padjadjaran.

Koentjaraningrat. 2007. Teori Religi. Jakarta: PT. Gramedia Pustaka Utama.

Mas Putra, I Gusti Ayu. 2001. Upakara Yadnya. Denpasar: Institut Hindu Dharma.

Nasruddin. 2013. Teori Munculnya Religi: Tinjauan Antropologis Terhadap
Unsur Kepercayaan Dalam Masyarakat. Jurnal Adabiyah Vol.XIII No. I/2013 Fakultas Adab dan Humaniora Universitas Islam Negeri Alaudin Makasar.

Nawir, Muhammad. 2013. Perubahan Sosial Masyarakat Dari Taradisional Ke Modern (Studi Kasus Masyarakat Di Desa Tosora Kabupaten Wajo). Jurnal Equilibrium, Volume I No.1 2013, hal. 75-86. Universitas Muhammadiyah Makasar.

Poerwanto, Hari. 2005. Kebudayaan Dan

Lingkungan Dalam Perspektif Antropologi. Yogyakarta: Pustaka Pelajar.

Sajogyo, Pudjiwati. 1985. Sosiologi Pembangunan: Ciri-Ciri Masyarakat Modern. Jakarta: Fakultas Pasca Sarjana IKIP Jakarta.

Sanderson, S.K. 2003. Makro Sosiologi. Terjemahan Farid Wajidi, S. Menno, Jakarta: PT Raja Grafindo Persada.

Setiadi, Elly M, dkk. 2016. Ilmu Sosial Budaya Dasar. Cetakan ke-12. Jakarta: Prenadamedia Group.

Soekanto, Soerjono. 2007. Sosiologi Suatu Pengantar. Jakarta: Raja Grafindo Persada.

Supartha, Ardhana, I.B. 2006. Pokok-Pokok Wariga. Penerbit: Paramita Surabaya.

Sumber Lontar: Lontar Medangkamulan dan Lontar Bagawan Garga. 